Review Article

\title{
Efficacy of Ultrasound-Guided Serratus Anterior Plane Block for Postoperative Analgesia in Patients Undergoing Breast Surgery: A Systematic Review and Meta-Analysis of Randomised Controlled Trials
}

\author{
Nian-Qiang Hu $\mathbb{D}^{1},{ }^{1}$ Qi-Qi He $\mathbb{D}^{2},{ }^{2}$ Lu Qian $\mathbb{D}^{1},{ }^{1}$ and Ji-Hong Zhu $\mathbb{D}^{1}$ \\ ${ }^{1}$ Department of Anesthesiology, Sir Run Run Shaw Hospital, School of Medicine, Zhejiang University, Hangzhou, China \\ ${ }^{2}$ Department of Nursing, Sir Run Run Shaw Hospital, School of Medicine, Zhejiang University, Hangzhou, China \\ Correspondence should be addressed to Ji-Hong Zhu; zhujihong2004@zju.edu.cn
}

Received 24 April 2021; Revised 25 August 2021; Accepted 7 October 2021; Published 25 October 2021

Academic Editor: Ratan banik

Copyright (c) 2021 Nian-Qiang Hu et al. This is an open access article distributed under the Creative Commons Attribution License, which permits unrestricted use, distribution, and reproduction in any medium, provided the original work is properly cited.

\begin{abstract}
Objective. Serratus anterior plane block (SAPB) provides effective thoracic analgesia. This systematic review and meta-analysis was conducted to assess the safety and efficacy of SAPB for postoperative analgesia after breast surgery. Methods. A systematic literature search was performed using Embase, PubMed, Web of Science, and the Cochrane Library for eligible randomised controlled trials. The primary outcomes involved the administration of intraoperative and postoperative opioids. The Grading of Recommendations, Assessment, Development and Evaluation (GRADE) approach was used for rating the quality of evidence for making recommendations. Results. Overall, 13 studies comprising 826 patients met the inclusion criteria (412 in the SAPB group and 414 in the control group). Patients treated with SAPB exhibited a significantly lower postoperative opioid consumption (mean difference, $-38.51 \mathrm{mg}$ of oral morphine equivalent; $95 \%$ confidence interval (CI), -60.97 to $-16.05 ; P<0.01 ; I^{2}=100 \%$ ), whereas no difference was observed in the intraoperative opioid consumption (mean difference, $-9.85 \mathrm{mg}$ of oral morphine equivalent; $95 \% \mathrm{CI},-19.52$ to $\left.-0.18 ; P=0.05 ; I^{2}=94 \%\right)$. In addition, SAPB significantly decreased the occurrence of postoperative nausea and vomiting (risk ratio, $0.32 ; 95 \% \mathrm{CI}, 0.19-0.55 ; P<0.05 ; I^{2}=38 \%$ ) and reduced pain scores during the postoperative period $(1 \mathrm{~h}$ : standardised mean difference (SMD), $-1.23 ; 95 \% \mathrm{CI},-2.00$ to $-0.45 ; I^{2}=92 \% ; 2 \mathrm{~h}$ : SMD, $-0.71 ; 95 \%$ CI, -1.00 to $-0.41 ; I^{2}=48 \%$; $4 \mathrm{~h}$ : SMD , $-1.52 ; 95 \% \mathrm{CI},-2.77$ to $-0.27 ; \mathrm{I}^{2}=95 \%$; $6 \mathrm{~h}$ : SMD, $-0.80 ; 95 \% \mathrm{CI},-1.51$ to $-0.08 ; I^{2}=81 \% ; 8 \mathrm{~h}$ : SMD, $-1.12 ; 95 \% \mathrm{CI}$, -1.98 to $-0.27 ; I^{2}=92 \% ; 12 \mathrm{~h}$ : SMD, $-0.78 ; 95 \% \mathrm{CI},-1.21$ to $-0.35 ; I^{2}=83 \%$; and $24 \mathrm{~h}$ : SMD, $-0.71 ; 95 \%$ CI, -1.20 to -0.23 ; $I^{2}=87 \% ; P<0.05$ for all). Conclusion. SAPB was safe and effective after breast surgery to relieve postsurgical pain. However, additional well-developed trials are required to validate these findings.
\end{abstract}

\section{Introduction}

According to global public health data, the most common type of cancer affecting women is breast cancer [1]. Surgical removal of the tumour is the primary treatment for breast cancer. However, postoperative pain continues to pose a problem in patients with breast cancer. Approximately $50 \%$ of patients who undergo breast surgery experience some degree of postoperative pain $[2,3]$. Severe pain hampers postoperative recovery [4] and prolongs the hospital stay [5]. In addition, the risk of progression of acute pain after breast surgery to chronic pain continues to remain [2]. Therefore, various techniques for analgesia such as intercostal block [6], erector spinae plane block [7], and paravertebral block [8] are reported to ease severe postsurgical pain.

Serratus anterior plane block (SAPB) is a recently described interfascial plane block technique to relieve thoracic pain by injecting a local anaesthetic into the plane between the latissimus dorsi muscle and serratus anterior muscle [9]. SAPB provides effective postoperative analgesia by blocking the lateral cutaneous branches of the thoracic intercostal nerves. Previous studies have demonstrated that SAPB can 
be used as a locoregional analgesic technique to reduce pain after breast surgery $[10,11]$. However, the effectiveness of this method for inducing analgesia remains controversial. A recent randomised controlled trial (RCT) indicated that a deep SAPB did not have any beneficial effects on postoperative analgesic outcomes such as pain scores and opioid consumption [12]. However, no systematic and convincing proof related to this has been reported.

Therefore, we performed this systematic review and meta-analysis of RCTs to explore the safety and effectiveness of the SAPB technique in breast surgery.

\section{Methods}

The present systematic review and meta-analysis was performed according to the guidelines of Preferred Reporting Items for Systematic Reviews and Meta-Analyses (PRISMA).

\subsection{Systematic Literature Search. A systematic literature} search was conducted using online databases, including Embase, PubMed, the Cochrane Library, and Web of Science, from the date of the establishment of the database to 31 March 2021 without any language restriction, and relevant RCTs were identified. The PubMed search criteria were as follows: (1) "serratus anterior block" (All Fields), "serratus anterior plane block" (All Fields), or "SAP block" (All Fields), (2) "sap block" (All Fields), "SAPB" (All Fields), and (3) "breast surgery" (All Fields), "breast cancer" (All Fields), "breast" (All Fields), or "breasts" (All Fields). Search strategies for other databases are shown in Supplementary Materials. Furthermore, we manually searched for the references in the relevant literature.

2.2. Selection Criteria and Data Extraction. Studies meeting the following inclusion criteria were included in this analysis: (1) participants: studies involving patients undergoing breast surgery; (2) intervention: studies clearly describing SAPB as an auxiliary technique for analgesia regardless of the timing of placement of the regional block before or after general anesthesia; (3) comparison: studies with no intervention, sham block, or incision infiltration; (4) outcome: studies reporting opioid consumption or postoperative pain score; and (5) study design: RCTs. The following articles were excluded from this study: (1) review or case reports; (2) trials on animals or research involving cadaver dissection; (3) conference abstracts; and (4) duplicate publications.

EndNote X9 was used to pick out authentic trials from duplicate ones. Two different authors checked the authenticity of the article titles and abstracts and carefully assessed the full texts to ensure that the articles met the eligibility criteria for this study. The data were collected from authentic publications and were independently cross-checked by the two authors. The data collected included the first author's name, sample size, age, surgery type, SAPB, general anesthesia techniques, comparison, postoperative opioids analgesia, and pain measurements. For trials with incomplete data, corresponding authors were contacted via e-mail to obtain the complete information.
2.3. Quality and Risk Assessment. The risk of bias in the publications included in this study was assessed using Cochrane Review Manager (Version 5.3; the Nordic Cochrane Centre, the Cochrane Collaboration, Copenhagen, Denmark, 2014). We used the following methods to assess bias: random sequence generation, allocation concealment, incomplete outcome data, double blinding, blinding of outcome assessment, and selective reporting. Each study was individually analysed by two reviewers and was classified into three groups: low risk, unclear risk, and high risk.

The quality of evidence was examined using the Grading of Recommendations Assessment, Development and Evaluation (GRADE) system to obtain results as per the following criteria: study design, inconsistency rating in results, risk of bias, and rating of indirectness of evidence. The quality of evidence was classified into 4 groups as high, moderate, low, and very low.

2.4. Primary and Secondary Outcomes. Intraoperative and postoperative $24 \mathrm{~h}$ opioid consumptions were the primary outcomes. The dose of different types of opioids consumed was converted to an equivalent dose of oral morphine according to GlobalRPh (http://www.globalrph.com/ narcotic). Secondary outcomes included the occurrence of adverse events and scores of postsurgical pain at different time points. Results from a previous study showed a correlation between the scores obtained on the visual analogue scale (VAS) and the numeric rating score (NRS) [13]; therefore, we analysed the pain scores obtained using these two scales. For studies that measured pain scores at different states, active pain scores were included in this meta-analysis.

2.5. Statistical Analysis. The meta-analysis was performed using Review Manager (version 5.3; the Nordic Cochrane Centre, the Cochrane Collaboration, Copenhagen, Denmark, 2014) and Stata V.12.0 (StataCorp LP, USA). A pooled risk ratio (RR) and 95\% confidence intervals (CIs) were calculated for dichotomous outcomes. $P<0.05$ was considered significant. Mean difference (MD) and 95\% confidence interval (CI) were measured using the same units for continuous data, whereas standardised mean difference (SMD) was used for different units. The data reported as medians (ranges) were converted to mean and standard deviation similar to those performed in previous studies $[14,15]$. We assessed heterogeneity among trials using the statistic. High heterogeneity may be observed because of methodological and clinical factors; therefore, despite the low value, the random effects model was implemented in this meta-analysis. Sensitivity analysis was performed to assess the stability of the primary outcome.

\section{Results}

3.1. Search Results. On the basis of our search strategy, we identified 1020 relevant trials. Among them, 238 trials were duplicate publications and 757 were excluded because after screening their abstracts, they were found to be irrelevant for this meta-analysis. Moreover, the remaining 25 full-text 


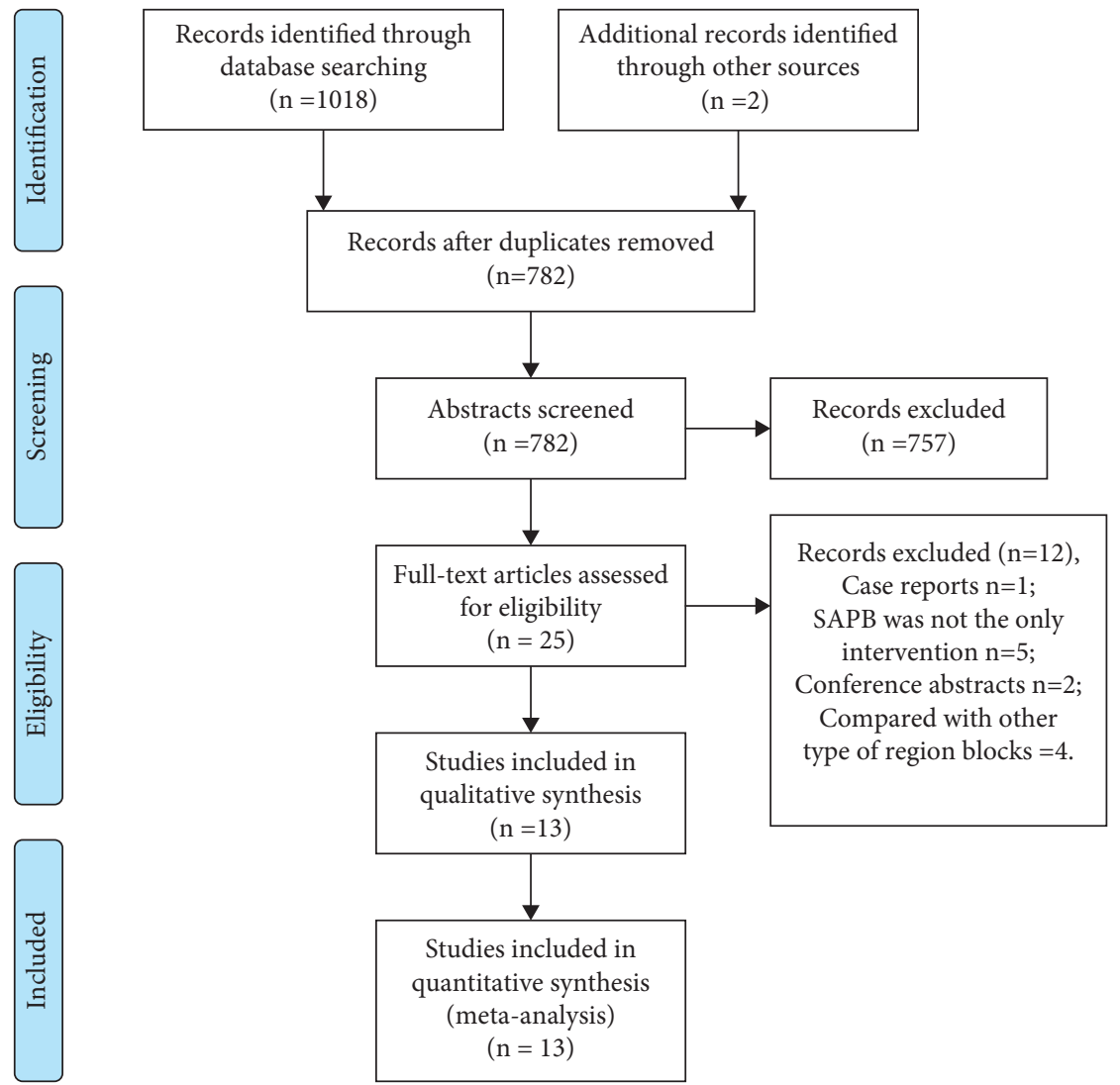

FIgURE 1: Flow chart of studies retrieval.

publications were carefully evaluated to check their eligibility. Furthermore, 12 trials were eliminated owing to the following reasons: they were case reports $(n=1)$ [16]; SAPB was not the only intervention $(n=5)$ [17-21]; they were conference abstracts $(n=2)[10,22]$; and SAPB was compared with other types of nerve blocks $(n=4)$ [11, 23-25]. Eventually, we included 13 eligible and authentic studies $[12,26-37]$ in this meta-analysis. The screening process for the literature is shown in Figure 1.

3.2. Study Characteristics. We analysed 13 RCTs consisting of 826 subjects who underwent breast surgery. The years of publication of these studies ranged from 2017 to 2021, and the sample size ranged from 40 to 116 . Overall, 7 trials, 5 trials, and 1 trial used bupivacaine $[26,27,30,32,34,36]$, ropivacaine [12, 29, 33, 35, 37], and levobupivacaine [28] as a local anaesthetic, respectively. The volume of the local anaesthetic was $20-40 \mathrm{~mL}$, and its concentration was $0.25 \%-$ $0.5 \%$. Overall, 12 trials evaluated pain scores using VAS, whereas 1 trial used NRS [35]. The details about the trials included in this meta-analysis are shown in Table 1.

3.3. Assessment of Bias. A total of 10 trials used the random sequence generation method [12, 27-37], 9 trials explained the allocation concealment [12, 26, 28, 30, 33, 35, 36], 3 trials explicitly described the method of double blinding $[12,28,36]$, and 9 trials described blinded assessors and evaluated attrition bias [12, 27, 28, 31, 33-37]. There was no selective reporting. The sample size of one trial [29] was not measured, and the other bias was classified into an unclear group. There were no reports of other biases, such as trial registration. The risk of bias is explained briefly in Figure 2.

3.4. Primary Outcomes. Intraoperative consumption of opioids was reported in 5 trials. The outcome showed a negligible difference between the two groups $(\mathrm{MD},-9.85 \mathrm{mg}$ of oral morphine equivalent; $95 \% \mathrm{CI},-19.52$ to -0.18 ; $P=0.05 ; I^{2}=94 \%$; Figure 3 ). Opioid consumption during the first postoperative $24 \mathrm{~h}$ was assessed in 11 trials. The forest plot data indicated that SAPB significantly decreased postoperative opioid consumption (MD, $-38.51 \mathrm{mg}$ of oral morphine equivalent; $95 \% \mathrm{CI},-60.97$ to $-16.05 ; P<0.01$; $=100 \%$; Figure 4).

3.5. Secondary Outcomes. Pain scores were evaluated at different time points during the first postoperative $24 \mathrm{~h}$. A forest plot showed that SAPB could significantly relieve postoperative pain (1 h: SMD, $-1.23 ; 95 \% \mathrm{CI},-2.00$ to -0.45 ; $P<0.05$; $=92 \% ; 2$ h: SMD, $-0.71 ; 95 \% \mathrm{CI},-1.00$ to -0.41 ; $P<0.05$; $=48 \%$; 4 h: SMD, $-1.52 ; 95 \% \mathrm{CI},-2.77$ to -0.27 ; $P<0.05 ; I^{2}=95 \%$; 6 h: SMD, $-0.80 ; 95 \% \mathrm{CI},-1.51$ to -0.08 ; $P<0.05 ;=81 \% ; 8$ h: SMD, $-1.12 ; 95 \% \mathrm{CI},-1.98$ to -0.27 ; $P<0.05$; $=92 \% ; 12$ h: SMD, $-0.78 ; 95 \% \mathrm{CI},-1.21$ to -0.35 ; 
TABLE 1: The characteristics of included studies.

\begin{tabular}{|c|c|c|c|c|c|c|c|c|}
\hline Study & $\begin{array}{l}\text { Sample } \\
\text { size }\end{array}$ & $\begin{array}{c}\text { Age } \\
\text { (years) }\end{array}$ & $\begin{array}{l}\text { Type of } \\
\text { surgery }\end{array}$ & General anesthesia & SAPB technique & Control group & $\begin{array}{c}\text { Postoperative } \\
\text { opioid analgesia }\end{array}$ & $\begin{array}{c}\text { Pain } \\
\text { measurement }\end{array}$ \\
\hline \multirow[t]{2}{*}{$\begin{array}{l}\text { Abdallah } \\
2021\end{array}$} & S: 20 & \multirow[t]{2}{*}{$18-80$} & \multirow{2}{*}{$\begin{array}{l}\text { Unilateral } \\
\text { partial or } \\
\text { simple } \\
\text { mastectomy }\end{array}$} & $\begin{array}{c}\text { Induction: } \\
\text { fentanyl } 1-3 \mu \mathrm{g} / \\
\mathrm{kg}, \text { propofol } \\
2-4 \mathrm{mg} / \mathrm{kg} \text {, and } \\
\text { rocuronium } \\
0.6 \mathrm{mg} / \mathrm{kg}\end{array}$ & $\begin{array}{l}\text { Position: lateral } \\
\text { decubitus; local } \\
\text { anesthetics: } \\
20 \mathrm{ml} \text { of } 0.5 \% \\
\text { ropivacaine }\end{array}$ & \multirow{2}{*}{$\begin{array}{l}\text { Sham block: } \\
1 \mathrm{ml} \text { sterile } \\
\text { saline } \\
\text { subcutaneously }\end{array}$} & \multirow{2}{*}{$\begin{array}{c}\text { Fentanyl } \\
\text { intravenous; } \\
\text { hydromorphone } \\
\text { intravenous; and } \\
\text { oxycodone oral } \\
\text { intake }\end{array}$} & \multirow[t]{2}{*}{ VAS } \\
\hline & C: 20 & & & $\begin{array}{c}\text { Maintenance: } \\
\text { desflurane } 2-6 \% \\
\text { in a } 50: 50 \text { mixture } \\
\text { of oxygen and air }\end{array}$ & $\begin{array}{l}\text { Timing: before } \\
\text { the general } \\
\text { anesthesia }\end{array}$ & & & \\
\hline \multirow{2}{*}{$\begin{array}{l}\text { Ahiskalioglu } \\
2020\end{array}$} & S: 20 & \multirow[t]{2}{*}{$18-60$} & \multirow{2}{*}{$\begin{array}{l}\text { Breast } \\
\text { reduction } \\
\text { surgery }\end{array}$} & $\begin{array}{c}\text { Induction: } \\
\text { fentanyl } 1-2 \mu \mathrm{g} / \\
\mathrm{kg} \text {, propofol } 2 \mathrm{mg} / \\
\mathrm{kg} \text {, and } \\
\text { rocuronium } \\
0.6 \mathrm{mg} / \mathrm{kg}\end{array}$ & $\begin{array}{l}\text { Position: lateral } \\
\text { decubitus; local } \\
\text { anesthetics: } \\
30 \mathrm{ml} \text { of } 0.25 \% \\
\text { bupivacaine }\end{array}$ & \multirow{2}{*}{$\begin{array}{l}\text { Sham block: } \\
2 \text { ml saline was } \\
\text { injected } \\
\text { subcutaneously }\end{array}$} & \multirow[t]{2}{*}{ Fentanyl PCA } & \multirow[t]{2}{*}{ VAS } \\
\hline & C: 20 & & & $\begin{array}{c}\text { Maintenance: } \\
\text { sevoflurane1-2\% } \\
\text { in a } 50: 50 \text { mixture } \\
\text { of oxygen and } \\
\mathrm{N}_{2} \mathrm{O}\end{array}$ & $\begin{array}{l}\text { Timing: before } \\
\text { the general } \\
\text { anesthesia }\end{array}$ & & & \\
\hline \multirow[t]{2}{*}{ Aslan 2020} & S: 20 & \multirow[t]{2}{*}{$18-70$} & \multirow[t]{2}{*}{$\begin{array}{l}\text { Modified } \\
\text { radical } \\
\text { mastectomy }\end{array}$} & $\begin{array}{c}\text { Induction: } \\
\text { fentanyl } 1 \mu \mathrm{g} / \mathrm{kg} \text {, } \\
\text { propofol } 2-3 \mathrm{mg} / \\
\mathrm{kg} \text {, and } \\
\text { rocuronium } \\
0.6 \mathrm{mg} / \mathrm{kg}\end{array}$ & $\begin{array}{l}\text { Position: supine } \\
\text { position; local } \\
\text { anesthetics: } \\
40 \mathrm{ml} \text { of } 0.25 \% \\
\text { bupivacaine }\end{array}$ & \multirow[t]{2}{*}{ No block } & \multirow[t]{2}{*}{ Morphine PCA } & \multirow[t]{2}{*}{ VAS } \\
\hline & C: 20 & & & $\begin{array}{c}\text { Maintenance: } 48 \% \\
\text { nitrogen oxide, } 2 \% \\
\text { sevoflurane, and } \\
50 \% \text { oxygen }\end{array}$ & $\begin{array}{c}\text { Timing: after the } \\
\text { general } \\
\text { anesthesia }\end{array}$ & & & \\
\hline \multirow[t]{2}{*}{ Bakeer 2020} & S: 58 & \multirow[t]{2}{*}{$18-60$} & \multirow{2}{*}{$\begin{array}{l}\text { Unilateral } \\
\text { modified } \\
\text { radical } \\
\text { mastectomy }\end{array}$} & $\begin{array}{c}\text { Induction: } \\
\text { fentanyl } 1 \mu \mathrm{g} / \mathrm{kg} \text {, } \\
\text { propofol } 2 \mathrm{mg} / \mathrm{kg} \text {, } \\
\text { and cisatracurium } \\
0.15 \mathrm{mg} / \mathrm{kg}\end{array}$ & $\begin{array}{l}\text { Position: lateral } \\
\text { position; local } \\
\text { anesthetics: } \\
30 \mathrm{ml} \text { of } 0.25 \% \\
\text { bupivacaine }\end{array}$ & \multirow[t]{2}{*}{ No block } & \multirow[t]{2}{*}{$\begin{array}{l}\text { Morphine } \\
\text { intravenous }\end{array}$} & \multirow[t]{2}{*}{ VAS } \\
\hline & C: 58 & & & $\begin{array}{l}\text { sevoflurane in } \\
\text { oxygen and air }\end{array}$ & $\begin{array}{l}\text { Timing: before } \\
\text { the general } \\
\text { anesthesia }\end{array}$ & & & \\
\hline \multirow[t]{2}{*}{ Bhan 2021} & S: 50 & \multirow[t]{2}{*}{$18-65$} & \multirow[t]{2}{*}{$\begin{array}{l}\text { Modified } \\
\text { radical } \\
\text { mastectomy }\end{array}$} & $\begin{array}{c}\text { Induction: } \\
\text { fentanyl } 2 \mu \mathrm{g} / \mathrm{kg} \text {, } \\
\text { propofol } 1-2 \mathrm{mg} / \\
\mathrm{kg} \text {, and } \\
\text { vecuronium } \\
0.1 \mathrm{mg} / \mathrm{kg}\end{array}$ & $\begin{array}{l}\text { Position: supine } \\
\text { position; local } \\
\text { anesthetics: } \\
0.4 \mathrm{~mL} \mathrm{kg-1} \mathrm{of} \\
0.375 \% \\
\text { ropivacaine } \\
\text { (maximum } \\
\text { volume of } \\
30 \mathrm{~mL} \text { ) }\end{array}$ & \multirow[t]{2}{*}{ No block } & \multirow[t]{2}{*}{$\begin{array}{c}\text { Other analgesia } \\
\text { drugs }\end{array}$} & \multirow[t]{2}{*}{ NRS } \\
\hline & C: 50 & & & $\begin{array}{l}\text { Maintenance: } 1 \\
\text { minimum alveolar } \\
\text { concentration } \\
\text { desflurane in } \\
\text { oxygen and air }\end{array}$ & $\begin{array}{l}\text { Timing: before } \\
\text { the general } \\
\text { anesthesia }\end{array}$ & & & \\
\hline
\end{tabular}


TABle 1: Continued.

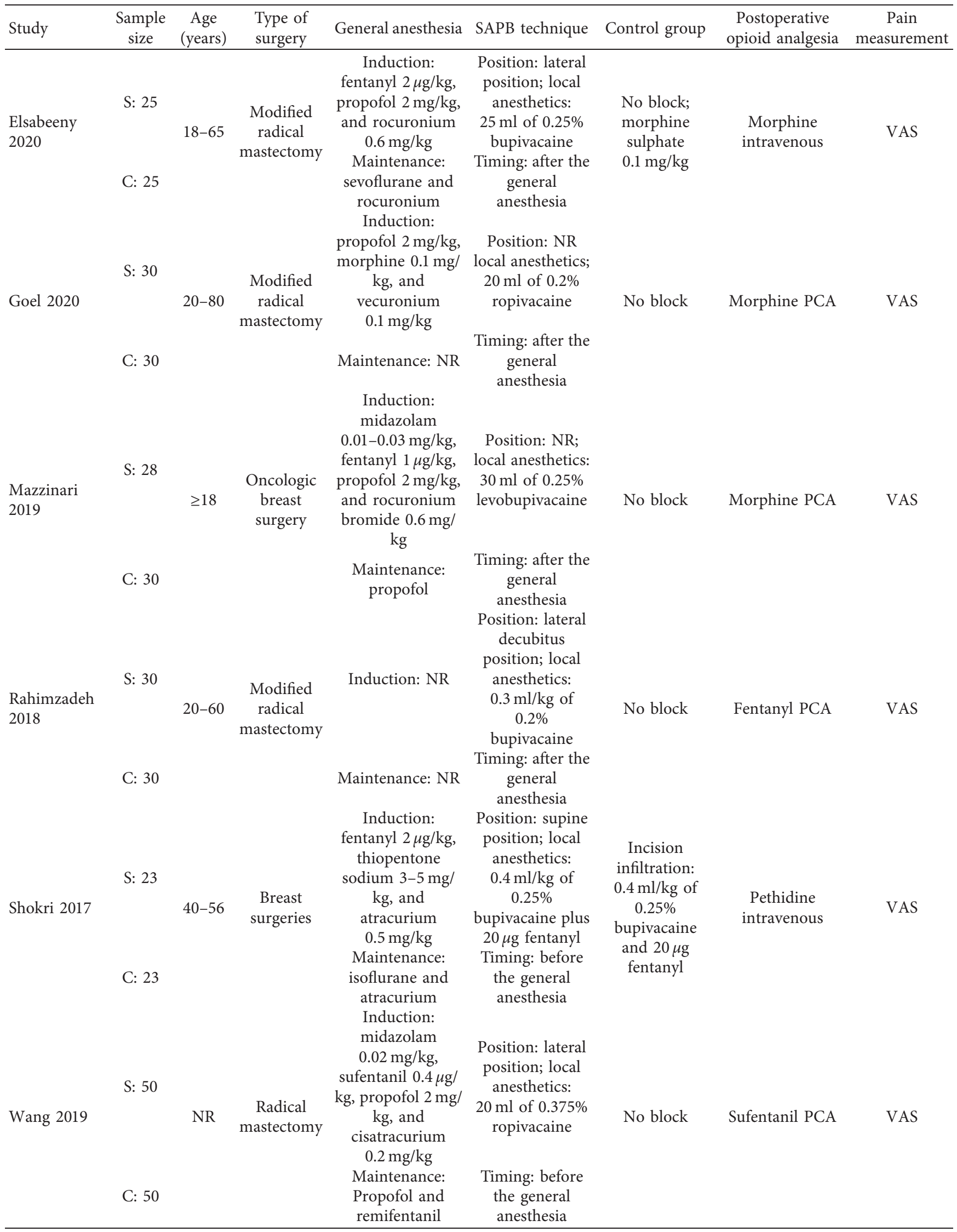


TABle 1: Continued.

\begin{tabular}{|c|c|c|c|c|c|c|c|c|}
\hline Study & $\begin{array}{l}\text { Sample } \\
\text { size }\end{array}$ & $\begin{array}{c}\text { Age } \\
\text { (years) }\end{array}$ & $\begin{array}{l}\text { Type of } \\
\text { surgery }\end{array}$ & General anesthesia & SAPB technique & Control group & $\begin{array}{l}\text { Postoperative } \\
\text { opioid analgesia }\end{array}$ & $\begin{array}{c}\text { Pain } \\
\text { measurement }\end{array}$ \\
\hline Yao 2019 & C: 34 & $18-60$ & $\begin{array}{l}\text { Unilateral } \\
\text { breast } \\
\text { cancer } \\
\text { surgery }\end{array}$ & $\begin{array}{c}\text { Induction: } \\
\text { sufentanil } 0.5 \mu \mathrm{g} / \\
\mathrm{kg} \text {, propofol } 2 \mathrm{mg} / \\
\mathrm{kg} \text {, and } \\
\text { cisatracurium } \\
0.15 \mathrm{mg} / \mathrm{kg}\end{array}$ & $\begin{array}{l}\text { Local } \\
\text { anesthetics: } \\
25 \mathrm{ml} \text { of } 0.5 \% \\
\text { ropivacaine; } \\
\text { timing: before } \\
\text { the general } \\
\text { anesthesia }\end{array}$ & $\begin{array}{c}\text { Sham block: } \\
\text { physiological } \\
\text { saline }\end{array}$ & Sufentanil PCA & VAS \\
\hline Yayik 2019 & C: 24 & $18-65$ & $\begin{array}{c}\text { Modified } \\
\text { radical } \\
\text { mastectomy }\end{array}$ & $\begin{array}{c}\text { Induction: } \\
\text { fentanyl } 1-2 \mu \mathrm{g} / \\
\mathrm{kg} \text {, propofol } 2 \mathrm{mg} / \\
\mathrm{kg} \text {, and } \\
\text { rocuronium } \\
0.6 \mathrm{mg} / \mathrm{kg} \\
\text { Maintenance: } \\
\text { sevoflurane } 1-2 \% \\
\text { in a } 50: 50 \text { mixture } \\
\text { of oxygen and } \\
\mathrm{N} 2 \mathrm{O}\end{array}$ & $\begin{array}{l}\text { Position: lateral } \\
\text { position; local } \\
\text { anesthetics: } \\
20 \mathrm{ml} \text { of } 0.25 \% \\
\text { bupivacaine }\end{array}$ & $\begin{array}{l}\text { Sham block: } \\
2 \text { ml saline was } \\
\text { injected } \\
\text { subcutaneously }\end{array}$ & Fentanyl PCA & VAS \\
\hline
\end{tabular}

SAPB, serratus anterior plane block; S, serratus anterior plane block group; C, control group; VAS, visual analogue scale; NRS, numeric rating score; PCA, patient-controlled analgesia devices; NR, not reported.

$P<0.05 ;=83 \%$; and $24 \mathrm{~h}: \mathrm{SMD},-0.71 ; 95 \% \mathrm{CI},-1.20$ to $-0.23 ; P<0.05 ;=87 \%$; Figure 5).

Sickness and vomiting were reported after surgery in 8 trials (postoperative nausea and vomiting, PONV). A forest plot showed a significantly low occurrence of PONV in the SAPB group (RR, 0.32; 95\% CI, 0.19-0.55; $P<0.05$; $=38 \%$; Figure 6). Procedure-related complications were not reported in the trials included in this analysis.

3.6. Publication Bias. We did not evaluate the publication bias because only a few studies were included in this analysis [38].

3.7. Sensitivity Analysis. Sensitivity analysis was performed for postoperative opioid consumption. The estimate of effect did not change, indicating the robustness of the formulated result (Figure 7).

3.8. GRADE Assessment. All studies included were RCTs. Most studies showed a relatively high. The "inconsistency" was classified as serious. Some trials reported median pain scores and opioid consumption. The "indirectness" was graded as serious. The GRADE levels were low and moderate for the outcomes. The total outcomes of the GRADE assessment are concisely shown in Table 2 .

\section{Discussion}

This systematic review and meta-analysis revealed that ultrasound-guided SAPB decreased opioid consumption (low quality) to a significant level and relieved pain after breast surgery (low quality). In addition, SAPB decreased the occurrence of PONV (moderate quality). Procedure-related complications were not seen in the studies included in the analysis.

Patients undergoing breast cancer surgery experience varying degrees of acute and chronic pain with an incidence of up to $60 \%$ [39]. Various analgesic techniques have been used in breast surgeries, including paravertebral block [8], intercostal block [6], and pectoral nerve block [40]. Paravertebral block and intercostal nerve block are associated with a risk of development of pneumothorax (0.3\%-11.4\%); therefore, these methods are not the preferred choice of anaesthesiologists [41, 42]. Effective control of pain after breast surgery is very important not only to more effectively manage acute pain but also to improve postoperative recovery [43].

The development of ultrasound-guided regional block and the introduction of new regional analgesia techniques have increased the safety and effectiveness of perioperative analgesia for thoracic surgery. Ultrasound-guided SAPB is a recently described regional block technique. It involves the injection of a local anaesthetic into the region between the serratus anterior and intercostal muscles [9]. The thoracic 


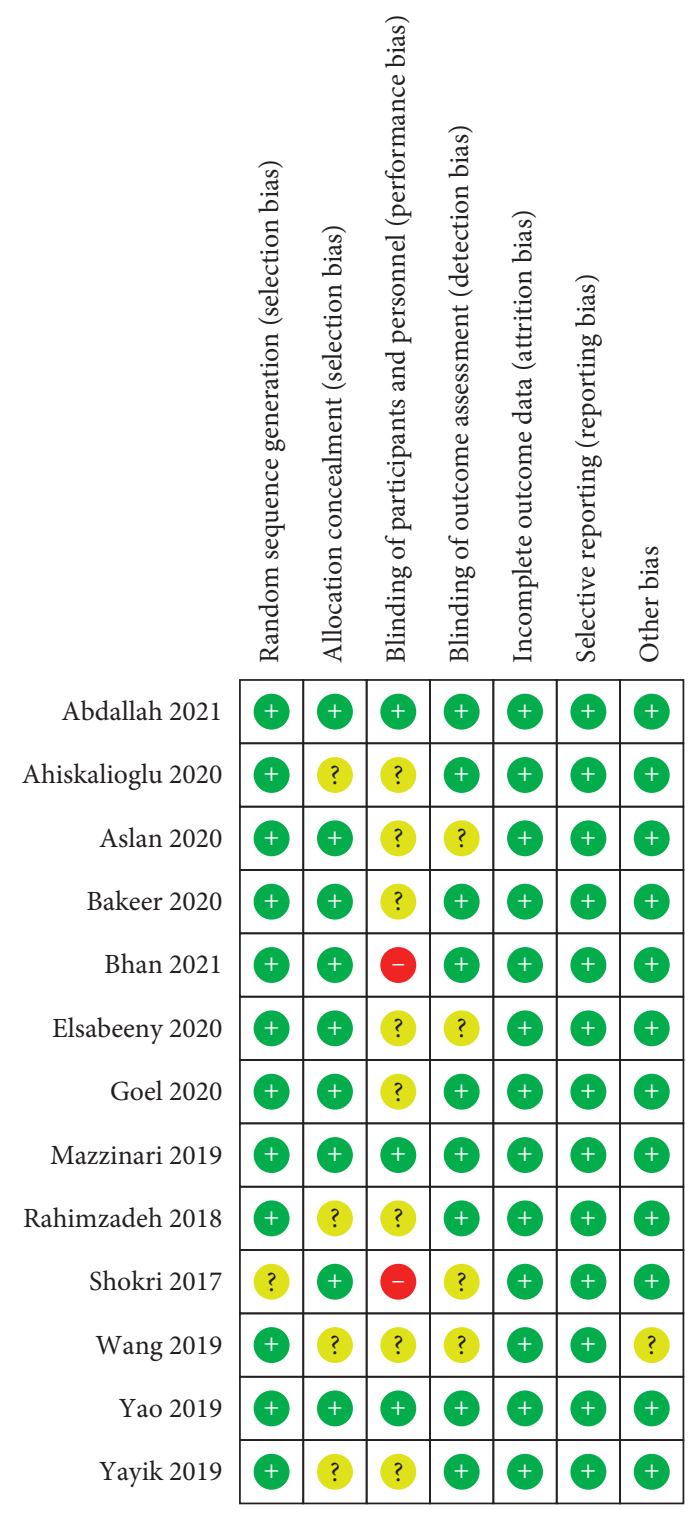

FIGURE 2: Risk bias of included studies.

region from $\mathrm{T} 2$ to $\mathrm{T} 9$ is blocked using this technique. A previous meta-analysis [44] reported that SAPB might provide effective analgesia after breast surgery; however, the control group in that meta-analysis included patients who received a paravertebral block.

The results of our meta-analysis revealed that SAPB remarkably decreased the levels of postoperative opioid consumption and decreased pain compared with that in the control group, which indicated that SAPB could provide effective analgesia after breast surgery. However, a recent RCT [12] showed that SAPB did not improve analgesic outcomes in patients who underwent ambulatory breast cancer surgery. This could be because "breast surgery," as the type of surgery being performed, is too generic a term and involves all degrees of trespass; therefore, comparison of the results obtained in this study with our results may be difficult. Moreover, deep SAPB alone was performed in a previous study, and Mayes et al. [45] reported that injecting methylene blue deep into the serratus anterior muscle did not produce a consistent spread area. The results of our meta-analysis revealed no difference in intraoperative opioid consumption between the two groups. This finding may be because the extent of SAPB was not sufficient to control intraoperative pain. Results similar to those of our study were reported by Alessandro et al. in patients undergoing thoracoscopic surgery [46]. 


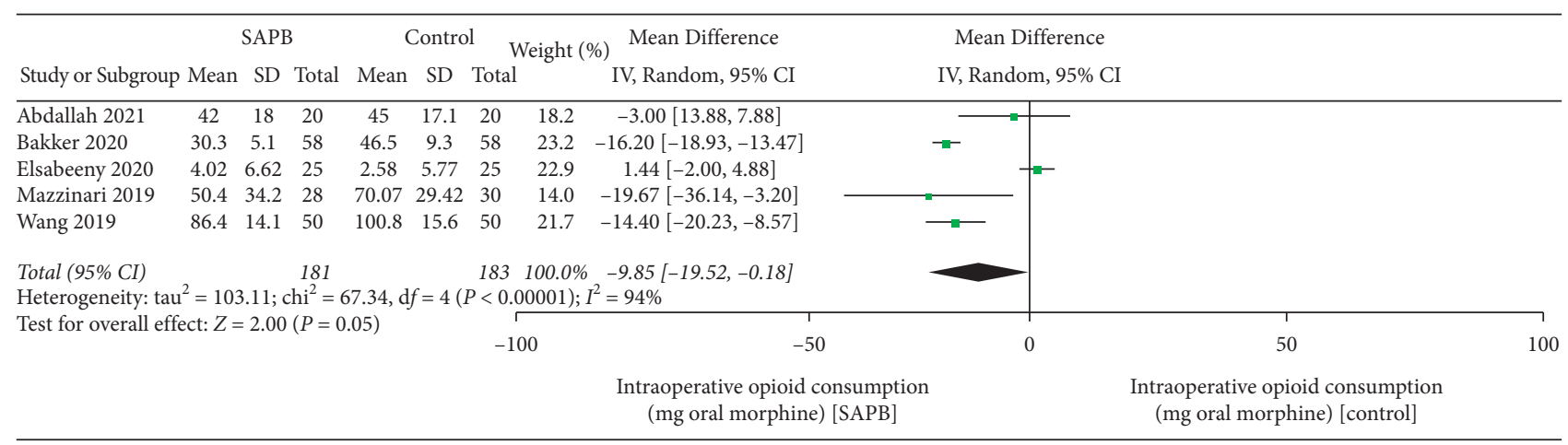

FIgURE 3: The forest plot of pooled analysis showing intraoperative opioid consumption.

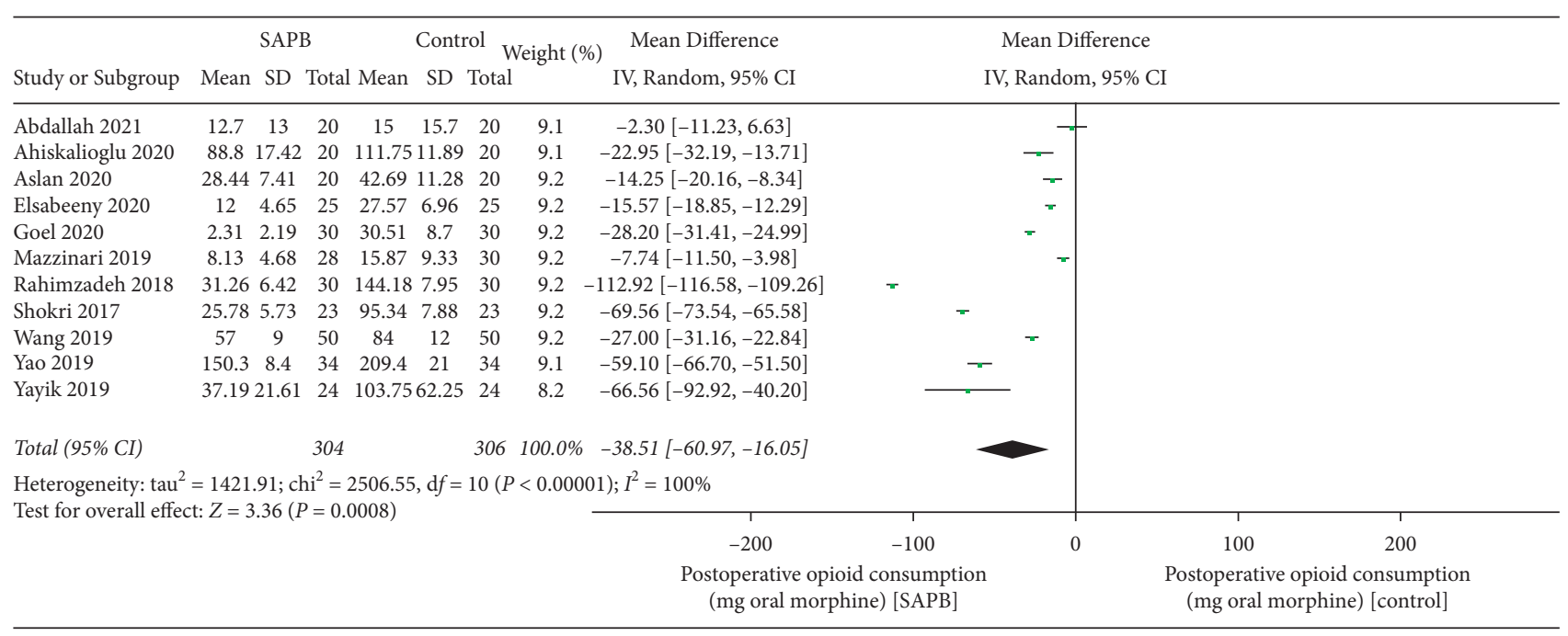

FIGURE 4: The forest plot of pooled analysis showing postoperative opioid consumption.

In addition, we observed that patients treated with SAPB had a significantly lower incidence of PONV. This may be a result of less opioid usage during the postoperative period. The results of a recent RCT with a large sample indicated that the incidence of PONV was $44.3 \%$ after general anesthesia [47]. Effective prevention of PONV is important in the implementation of enhanced recovery after surgery. Reduction of PONV is useful in expediting discharge for outpatients [48].

Procedure-related complications were not seen in the studies included in this analysis. SAPB is a relatively safe technique of regional block, and potential block-related complications such as bleeding and infection at the puncture site have not been reported. To date, only a case report by
Desai described the development of pneumothorax following SABP in a patient undergoing wire-guided wide local excision of a lump in the right breast [49]. However, as a novel regional block technique, high-quality trials are required to ensure the safety of SAPB.

Our meta-analysis had some limitations. The analysis was performed with a limited number of participants. Therefore, studies with a larger sample size should be performed in the future. Furthermore, a high level of clinical heterogeneity may be present because of the various general and local anesthetics administered to the patients. We were unable to compare the advantages and disadvantages of SAPB with other techniques of regional anesthesia because of an insufficient number of RCTs pertaining to this topic. 


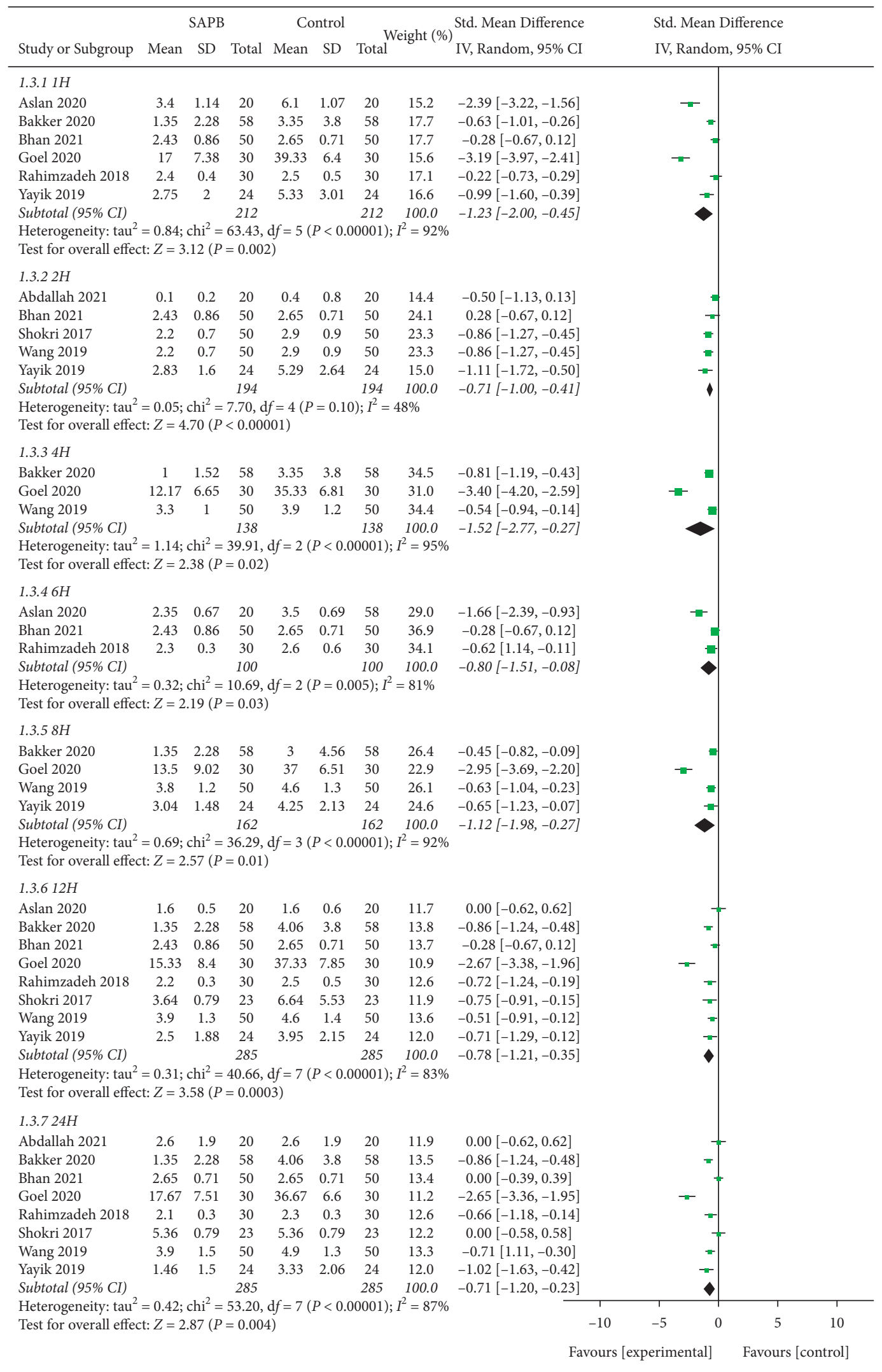

FIGURE 5: The forest plot of pooled analysis showing postoperative pain scores ( $\mathrm{H}$, hour). 


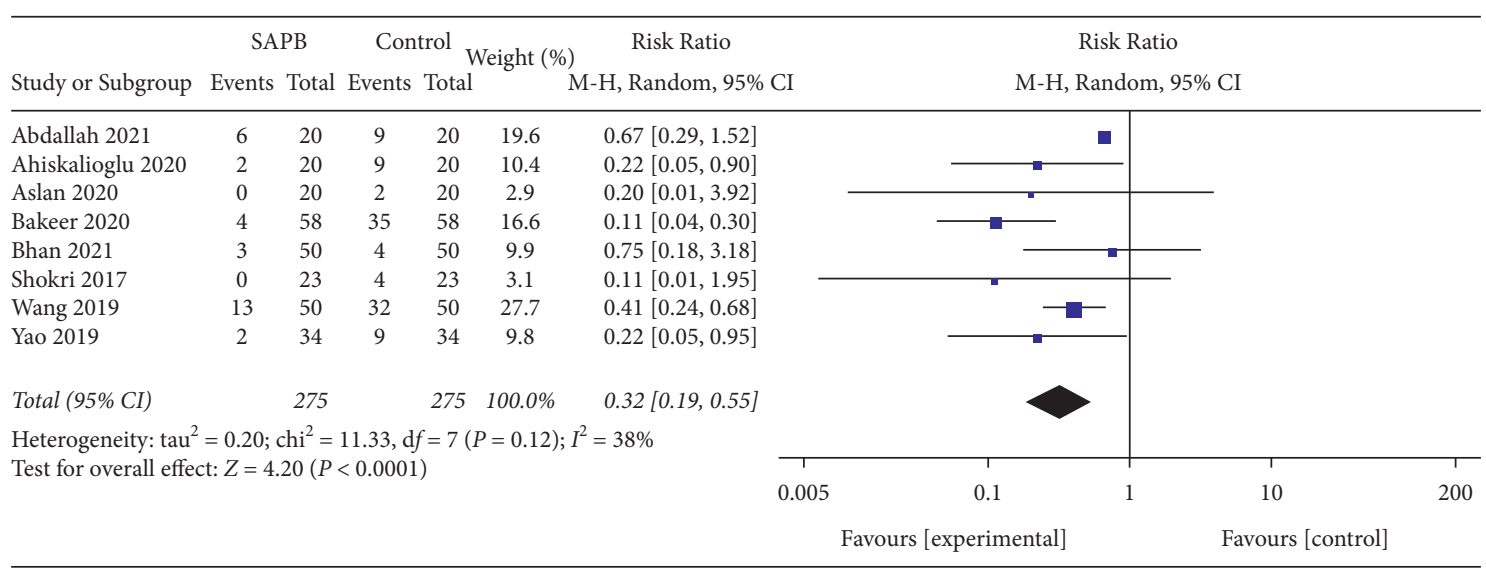

FIgURE 6: The forest plot of pooled analysis showing the incidence of postoperative nausea and vomiting.

Meta-analysis estimates, given named study is omitted

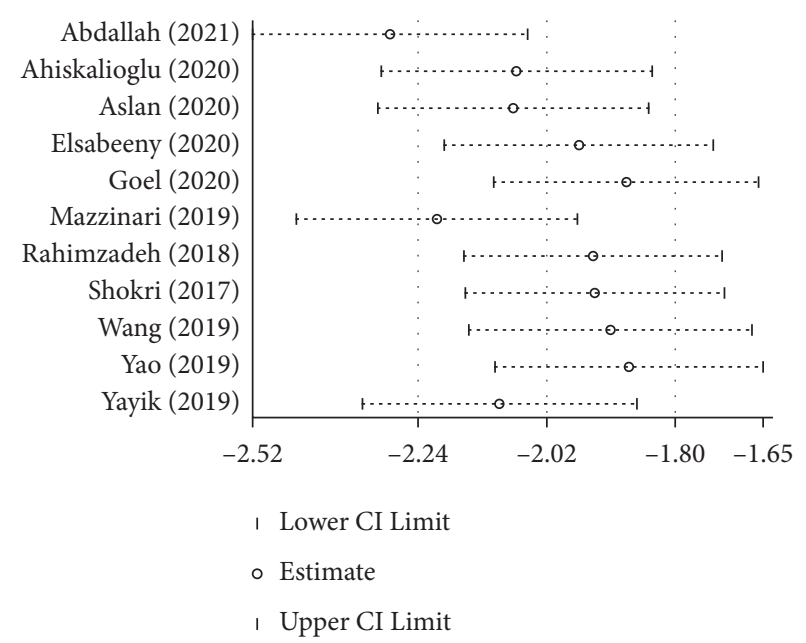

FIgURE 7: Sensitivity analysis for postoperative opioid consumption.

TABLE 2: The summary of the GRADE evaluation.

\begin{tabular}{|c|c|c|c|}
\hline Outcome & MD/SMD/RR (95\% CI) & Quality of evidence & Reasons \\
\hline Intraoperative opioid consumption & $-9.85(-19.52,-0.18)$ & $\square \square \hat{x} \hat{x}$ LOW & $\begin{array}{l}\text { Indirectness was "serious"; ; } \\
\text { inconsistency was "serious" }\end{array}$ \\
\hline Postoperative opioid consumption & $-38.51(-60.97,-16.05)$ & $\square \square \hat{x} \hat{x}$ LOW & $\begin{array}{l}\text { Indirectness was "serious" } \\
\text { inconsistency was "serious" }\end{array}$ \\
\hline Pain score at $1 \mathrm{H}$ postoperatively & $-1.23(-2.00,-0.45)$ & $\square \square \hat{x} \hat{x}$ LOW & $\begin{array}{l}\text { Indirectness was "serious"; } \\
\text { inconsistency was "serious" }\end{array}$ \\
\hline Pain score at $2 \mathrm{H}$ postoperatively & $-0.71(-1.00,-0.41)$ & $\square \square \hat{x} \hat{x}$ LOW & $\begin{array}{l}\text { Indirectness was "serious"; } \\
\text { inconsistency was "serious" }\end{array}$ \\
\hline Pain score at $4 \mathrm{H}$ postoperatively & $-1.52(-2.77,-0.27)$ & $\square \square \hat{x} \hat{x}$ LOW & $\begin{array}{l}\text { Indirectness was "serious"; } \\
\text { inconsistency was "serious" }\end{array}$ \\
\hline Pain score at $6 \mathrm{H}$ postoperatively & $-0.80(-1.51,-0.08)$ & $\square \square \hat{x} \hat{x}$ LOW & $\begin{array}{l}\text { Indirectness was "serious"; } \\
\text { inconsistency was "serious" }\end{array}$ \\
\hline Pain score at $8 \mathrm{H}$ postoperatively & $-1.12(-1.98,-0.27)$ & $\square \square \hat{x} \hat{x}$ LOW & $\begin{array}{l}\text { Indirectness was "serious"; } \\
\text { inconsistency was "serious" }\end{array}$ \\
\hline Pain score at $12 \mathrm{H}$ postoperatively & $-0.78(-1.21,-0.35)$ & $\square \square \hat{x} \hat{x}$ LOW & $\begin{array}{l}\text { Indirectness was "serious"; } \\
\text { inconsistency was "serious" }\end{array}$ \\
\hline Pain score at $24 \mathrm{H}$ postoperatively & $-0.71(-1.20,-0.23)$ & $\square \square \hat{x} \hat{x}$ LOW & $\begin{array}{l}\text { Indirectness was "serious"; } \\
\text { inconsistency was "serious" }\end{array}$ \\
\hline Incidence of PONV & $0.32(0.19,0.55)$ & $\square \square \square \hat{x}$ MODERATE & Inconsistency was "serious" \\
\hline
\end{tabular}

SMD, standardised mean difference; $\mathrm{RR}$, risk ratio; $\mathrm{H}$, hour; PONV, postoperative nausea and vomiting. 


\section{Conclusion}

SAPB is safe and effective in inducing postoperative analgesia after breast surgery. However, well-designed trials are required to validate these findings.

\section{Data Availability}

All data generated or analysed during this study are included within this published article and its supplementary information files.

\section{Conflicts of Interest}

The authors declare that they have no conflicts of interest regarding the publication of this paper.

\section{Supplementary Materials}

Search strategies for other databases. . (Supplementary Materials)

\section{References}

[1] S. Loibl, P. Poortmans, M. Morrow, C. Denkert, and G. Curigliano, "Breast cancer," Lancet, vol. 397, no. 10286, pp. 1750-1769, London, England, 2021.

[2] L. Wang, G. H. Guyatt, S. A. Kennedy et al., "Predictors of persistent pain after breast cancer surgery: a systematic review and meta-analysis of observational studies," Canadian Medical Association Journal, vol. 188, no. 14, pp. E352-e361, 2016.

[3] R. Gärtner, M.-B. Jensen, J. Nielsen, M. Ewertz, N. Kroman, and H. Kehlet, "Prevalence of and factors associated with persistent pain following breast cancer surgery," Jama, vol. 302, no. 18, pp. 1985-1992, 2009.

[4] F. E. Shapiro, "Anesthesia for outpatient cosmetic surgery," Current Opinion in Anaesthesiology, vol. 21, no. 6, pp. 704710, 2008.

[5] G. Brodner, N. Mertes, H. Buerkle, M. A. E. Marcus, and H. Van Aken, "Acute pain management: analysis, implications and consequences after prospective experience with 6349 surgical patients," European Journal of Anaesthesiology, vol. 17, no. 9, pp. 566-575, 2000.

[6] R. Vemula, M. Kutzin, G. Greco, and T. Kutzin, "The use of intercostal nerve blocks for implant-based breast surgery," Plastic and Reconstructive Surgery, vol. 132, no. 1, pp. 178e180e, 2013.

[7] H.-F. Li, Q.-H. Shen, X.-Y. Zhou, and X. Shen, "Analgesic effects of erector spinae plane block for patients after breast surgery: a systematic review and meta-analysis," Journal of International Medical Research, vol. 49, no. 3, Article ID 52199956, 2021.

[8] A. Chhabra, A. Roy Chowdhury, H. Prabhakar et al., "Paravertebral anaesthesia with or without sedation versus general anaesthesia for women undergoing breast cancer surgery," Cochrane Database of Systematic Reviews, vol. 2021, no. 2, Article ID Cd012968, 2021.

[9] R. Blanco, T. Parras, J. G. McDonnell, and A. Prats-Galino, "Serratus plane block: a novel ultrasound-guided thoracic wall nerve block," Anaesthesia, vol. 68, no. 11, pp. 1107-1113, 2013.

[10] A. Ahiskalioglu, A. M. Yayik, U. Demir et al., "Ultrasound guided bilateral serratus plane block for breast reduction surgery: a randomized controlled double blind study," Regional Anesthesia and Pain Medicine, vol. 42, 2017.

[11] K. Gupta and V. Chan, "Comparison of ultrasound guided paravertebral block with serratus plane block for modified radical mastectomy," Regional Anesthesia and Pain Medicine, vol. 42, 2017.

[12] F. W. Abdallah, V. Patel, C. Madjdpour, T. Cil, and R. Brull, "Quality of recovery scores in deep serratus anterior plane block vs. sham block in ambulatory breast cancer surgery: a randomised controlled trial," Anaesthesia, vol. 76, no. 9, pp. 1190-1197, 2021.

[13] P. Wiriyakijja, S. Porter, S. Fedele et al., "Validity and responsiveness of pain rating scales in patients with chronic oral mucosal diseases," Oral Diseases, 2021.

[14] D. Luo, X. Wan, J. Liu, and T. Tong, "Optimally estimating the sample mean from the sample size, median, mid-range, and/ or mid-quartile range," Statistical Methods in Medical Research, vol. 27, no. 6, pp. 1785-1805, 2018.

[15] X. Wan, W. Wang, J. Liu, and T. Tong, "Estimating the sample mean and standard deviation from the sample size, median, range and/or interquartile range," BMC Medical Research Methodology, vol. 14, no. 1, p. 135, 2014.

[16] Y. Ohgoshi, M. Yokozuka, and K. Terajima, "Serratus-Intercostal plane block for brest surgery," Masui. The Japanese journal of anesthesiology, vol. 64, pp. 610-614, 2015.

[17] D. A. E. K. Rashwan, A. R. Mohammed, S. A. Kasem Rashwan, A. S. Abd El Basset, and H. A. Nafady, "Efficacy of serratus anterior plane block using bupivacaine/magnesium sulfate versus bupivacaine/nalbuphine for mastectomy: a randomized, double-blinded comparative study," Anesthesiology and Pain Medicine, vol. 10, no. 3, Article ID e103141, 2020.

[18] P. Sirohiya, V. Kumar, N. Gupta, S. Bharati, R. Garg, and S. Mishra, "Effect of adding dexamethasone to ropivacaine for ultrasound-guided serratus anterior plane block in patients undergoing modified radical mastectomy: a preliminary trial," Indian Journal of Anaesthesia, vol. 64, no. 12, pp. 1032-1037, 2020.

[19] L. Huang, L. Zheng, B. Wu et al., "Effects of ropivacaine concentration on analgesia after ultrasound-guided serratus anterior plane block: a randomized double-blind trial," Journal of Pain Research, vol. 13, pp. 57-64, 2020.

[20] M. Matsumoto, E. M. Flores, P. P. Kimachi et al., "Benefits in radical mastectomy protocol: a randomized trial evaluating the use of regional anesthesia," Scientific Reports, vol. 8, no. 1, p. 7815, 2018.

[21] W. Wang, "Ultrasound-guided pectoral nerve block I and serratus-intercostal plane block Alleviate postoperative pain in patients undergoing modified radical mastectomy," Pain Physician, vol. 4, no. 22, pp. E315-e323, 2019.

[22] S. K. Youn, B. Hong, Y. Jo, Y. Kim, and Y. Ko, "Is thoracic interfascial block needed for breast lumpectomy surgery? yes," Regional Anesthesia and Pain Medicine, vol. 43, pp. e93-e94, 2018.

[23] D. Bhoi, A. Chhabra, V. K. Mohan, P. Talawar, A. Srivastava, and K. Kataria, "Post mastectomy pain syndrome: can it be influenced by regional block? a longitudinal study based on retrospective data," Regional Anesthesia and Pain Medicine, vol. 42, p. e191, 2017.

[24] S. M. Amin, E. Abdelrahman, E. El Shahat Afify, and E. Elsayed, "Ultrasound-guided serratus anterior plane block versus thoracic paravertebral block for postmastectomy analgesia," Benha Medical Journal, vol. 35, no. 3, p. 429, 2018.

[25] K. Gupta, K. Srikanth, K. Girdhar, and V. Chan, "Analgesic efficacy of ultrasound-guided paravertebral block versus 
serratus plane block for modified radical mastectomy: a randomised, controlled trial," Indian Journal of Anaesthesia, vol. 61, no. 5, pp. 381-386, 2017.

[26] H. Shokri and A. A. Kasem, "Efficacy of postsurgical ultrasound guided serratus intercostal plane block and wound infiltration on postoperative analgesia after female breast surgeries. A comparative study," Egyptian Journal of Anaesthesia, vol. 33, no. 1, pp. 35-40, 2017.

[27] P. Rahimzadeh, F. Imani, F. Imani, and S. H. R. Faiz, "Impact of the ultrasound-guided serratus anterior plane block on post-mastectomy pain: a randomised clinical study," Turkish Journal of Anesthesia and Reanimation, vol. 46, pp. 388-392, 2018.

[28] G. Mazzinari, L. Rovira, A. Casasempere et al., "Interfascial block at the serratus muscle plane versus conventional analgesia in breast surgery: a randomized controlled trial," Regional Anesthesia and Pain Medicine, vol. 44, no. 1, pp. 52-58, 2019.

[29] H. J. Wang, "Comparison of ultrasound-guided serratus anterior plane block and erector spinae plane blockperioperatively in radical mastectomy," Zhonghua Yi Xue Za Zhi, vol. 99, pp. 1809-1813, 2019.

[30] G. Aslan, O. Avc1, O. Gündoğdu et al., "The effect of postoperative serratus anterior plane block on postoperative analgesia in patients undergoing breast surgery," Turkish journal of surgery, vol. 36, no. 4, pp. 374-381, 2020.

[31] A. H. Bakeer, K. M. Kamel, A. S. Abdel Galil, A. A. Ghoneim, A. H. Abouel Soud, and M. E. Hassan, "Modified pectoral nerve block versus serratus block for analgesia following modified radical mastectomy: a randomized controlled trial," Journal of Pain Research, vol. 13, pp. 1769-1775, 2020.

[32] W. Y. Elsabeeny, N. N. Shehab, M. A. Wadod, and M. A. Elkady, "Perioperative analgesic modalities for breast cancer surgeries: a prospective randomized controlled trial," Journal of Pain Research, vol. 13, pp. 2885-2894, 2020.

[33] A. Goel, S. Palta, R. Saroa, and P. Saxena, "Efficacy of serratus anterior muscle block as a part of multimodal analgesic regimen in patients undergoing modified radical mastectomy," Sri Lankan Journal of Anaesthesiology, vol. 28, no. 2, pp. 125-130, 2020.

[34] A. Ahiskalioglu, A. M. Yayik, U. Demir et al., "Preemptive analgesic efficacy of the ultrasound-guided bilateral superficial serratus plane block on postoperative pain in breast reduction surgery: a prospective randomized controlled study," Aesthetic Plastic Surgery, vol. 44, no. 1, pp. 37-44, 2020.

[35] S. Bhan, S. Mishra, N. Gupta et al., "A prospective randomised study to assess the analgesic efficacy of serratus anterior plane (SAP) block for modified radical mastectomy under general anaesthesia," Turkish journal of anaesthesiology and reanimation, vol. 49, no. 2, pp. 124-129, 2021.

[36] Y. Yao, J. Li, H. Hu, T. Xu, and Y. Chen, "Ultrasound-guided serratus plane block enhances pain relief and quality of recovery after breast cancer surgery," European Journal of Anaesthesiology, vol. 36, no. 6, pp. 436-441, 2019.

[37] A. M. Yayik, A. Ahiskalioglu, M. M. Sulak, E. O. Ahiskalioglu, and H. Alic1, "The effect of ultrasound guided superficial serratus plane block for acute post mastectomy pain after modified radical mastectomy and axillary lymph node dissection: a randomized controlled study," JARSS, vol. 27, pp. 45-51, 2019.

[38] J. A. C. Sterne, A. J. Sutton, J. P. A. Ioannidis et al., "Recommendations for examining and interpreting funnel plot asymmetry in meta-analyses of randomised controlled trials," BMJ, vol. 343, no. 1, p. d4002, 2011.
[39] K. G. Andersen and H. Kehlet, "Persistent pain after breast cancer treatment: a critical review of risk factors and strategies for prevention," The Journal of Pain, vol. 12, no. 7, pp. 725-746, 2011.

[40] M. Meißner, E. Austenfeld, P. Kranke et al., "Pectoral nerve blocks for breast surgery," European Journal of Anaesthesiology, vol. 38, no. 4, pp. 383-393, 2021.

[41] M. El Ghamry and A. Amer, "Role of erector spinae plane block versus paravertebral block in pain control after modified radical mastectomy. A prospective randomised trial," Indian Journal of Anaesthesia, vol. 63, no. 12, pp. 1008-1014, 2019.

[42] A. D. Niesen, A. K. Jacob, L. A. Law, H. P. Sviggum, and R. L. Johnson, "Complication rate of ultrasound-guided paravertebral block for breast surgery," Regional Anesthesia and Pain Medicine, vol. 45, no. 10, pp. 813-817, 2020.

[43] G. E. Woodworth, R. M. J. Ivie, S. M. Nelson, C. M. Walker, and R. B. Maniker, "Perioperative breast analgesia," Regional Anesthesia and Pain Medicine, vol. 42, no. 5, pp. 609-631, 2017.

[44] M. Chong, N. Berbenetz, K. Kumar, and C. Lin, "The serratus plane block for postoperative analgesia in breast and thoracic surgery: a systematic review and meta-analysis," Regional Anesthesia and Pain Medicine, vol. 4, Article ID 100982, 2019.

[45] J. Mayes, E. Davison, P. Panahi et al., "An anatomical evaluation of the serratus anterior plane block," Anaesthesia, vol. 71, no. 9, pp. 1064-1069, 2016.

[46] A. De Cassai, A. Boscolo, F. Zarantonello et al., "Serratus anterior plane block for video-assisted thoracoscopic surgery," European Journal of Anaesthesiology, vol. 38, no. 2, pp. 106-114, 2021.

[47] A. Turan, H. Essber, W. Saasouh et al., "Effect of intravenous acetaminophen on postoperative hypoxemia after abdominal surgery," Jama, vol. 324, no. 4, pp. 350-358, 2020.

[48] J. R. Majumdar, E. Vertosick, M. Assel et al., "Reduction of postoperative nausea and vomiting and unplanned extended stays in outpatient plastic surgeries with a standardized protocol," Journal of Clinical Anesthesia, vol. 74, Article ID 110419, 2021

[49] M. Desai, M. K. Narayanan, and A. Venkataraju, "Pneumothorax following serratus anterior plane block," Anaesthesia reports, vol. 8, no. 1, pp. 14-16, 2020. 